\title{
Sociobiology
}

RESEARCH ARTICLE - BEES

\section{Nesting Biology of the Solitary Ground-Nesting Bee Diadasina riparia (Apidae: Emphorini)}

\author{
Herbeson O. J. MARTINS ${ }^{1}$, Gilson P. AMORIM-Junior ${ }^{2}$, William O. SABINO ${ }^{3}$, Vinina S. Ferreira ${ }^{2}$
}

1 - Programa de Pós-Graduação em Entomologia, Faculdade de Filosofia, Ciências e Letras de Ribeirão Preto, Universidade de São Paulo, Ribeirão Preto, Brazil

2 - Universidade Federal do Vale do São Francisco, Colegiado de Ciências Biológicas, Petrolina, Brazil

3 - Instituto Tecnológico Vale, Pará, Brazil

\section{Article History}

\section{Edited by}

Evandro Nascimento Silva, UEFS, Brazil

Received 03 April 2021

Initial acceptance 31 July 2021

Final acceptance 08 October 2021

Publication date 24 November 2021

\section{Keywords}

Fossorial bee, Caatinga, oligolectic bees, nesting behavior.

\section{Corresponding author}

Herbeson Ovidio de Jesus Martins (ID)

Departamento de Biologia, Faculdade de

Filosofia, Ciências e Letras de Ribeirão

Preto, Universidade de São Paulo

Av. Bandeirantes no 3900, CEP 14040-901

Ribeirão Preto, São Paulo, Brasil.

E-Mail: herbeson.bio@hotmail.com

\begin{abstract}
We described the nesting behavior and ecology of Diadasina riparia from an urban dry forest fragment. The nests of $D$. riparia were shallow with a circular entrance, closed by a mud plug, from which a straight vertical tunnel ending in one or more brood cells. Most females need one day for construction and provisioning the nest. The natural enemies were flies of the Anthrax genus, the cleptoparasitic bees Leiopodus trochantericus, and Mutillidae wasps. The feature about the life history, nest architecture, materials used, pollen provision behavior, and associated organisms of this species allows comparison with other emphorines species.
\end{abstract}

\section{Introduction}

Bees are the most effective pollinators of nature and thus ensure the maintenance of crops and wild plants (Nabhan \& Buchmann, 1997; Klein et al., 2007). They belong to the Apoidea superfamily. It is estimated that there are more than four thousand genera and 25 to 30 thousand species distributed in different regions of the world (Michener, 2007), of which 20.507 have been described (Ascher \& Pickering, 2019). Solitary bees comprise $85 \%$ of known species, and among them, females make their own nest, supply them with food, and die before the next generation emerges (Batra, 1984; Michener, 2007). These bees can use different substrates for nesting, and the ground is the most widespread among all groups (Michener, 1964; 2007; Harmon-Threatt, 2020). On the other hand, the number of studies focused on the groundnesting bees is still low compared to the guild of bees nesting in aboveground substrates. This scarcity of studies is mainly due to the difficulty of finding nests in the field.

Amid the ground-nesting solitary bees, Diadasina (Moure) is a genus of the Emphorini tribe composed of eight species with distribution restricted to Argentina, Bolivia, Brazil, Panama, and Paraguay (Moure \& Melo, 2012). In Brazil, this genus is represented by the species $D$. distincta (Holmberg), D. monticola Moure, D. paraensis (Ducke), D. parahybensis (Cockerell), and D. riparia (Ducke) (Moure \& Melo, 2012). The biology and nesting behavior of Diadasina species is poorly known, and the studies are restricted to the Neotropical species D. distincta (Martins \& Antonini, 1994; Hazeldine, 1997). 
Here we present data and observations on the nesting biology of $D$. riparia, a solitary bee species with distribution restricted to South America (Moure \& Melo, 2012). Information about the nest architecture, foraging behavior, life cycle, sex ratio, and natural enemies are provided.

\section{Material and Methods}

\section{Study site}

The study was carried out in a fragment of Caatinga (seasonally dry forest) at Universidade Federal do Vale do São Francisco (9¹9'44,2'’ S, 40³3'”30,1 W), municipality of Petrolina, Pernambuco state, Brazil. The climate is BSh, according to the Köppen classification. And it is characterized by low rainfall with an annual average precipitation of 433 $\mathrm{mm}$. Two well-defined seasons are observed: the dry season from May to October and the rainy from November to April (Amorim-Neto, 1989).

\section{Data collection and analysis}

We exposed and measured the nest architectures using a digital caliper. After that, we drew them on the original scale utilizing the software Adobe Photoshop and Adobe Illustrator version CC 2018. We collected females of D. riparia at the beginning of the nesting process. To identify individuals, we marked them on the thorax with a non-toxic pen (Uni Posca ®; Tokyo, Japan) with different colors combinations.

We conducted observations weekly, from October 2018 until July 2019. We monitored six females during the construction of nine nests from the initial digging through nest closure. We applied the focal animal and ad libitum methods to observe the following female activities to build their nests: time spent constructing each brood cell, provisioning resources trips, and the behavior near the nesting area. We measured the nest density in the area using a $1-\mathrm{m}^{2}$ quadrat to count the number of nests during the nesting season. To obtain the sex ratio and time of emergence, we placed clear plastic cups over 200 nest entrances.

We collected some specimens and sent them to the identification. The vouchers are deposited in the Entomological Collection Padre Jesus Santiago Moure of the Department of Zoology at Universidade Federal do Paraná (DZUP). Nest structures are deposited in the Entomology Laboratory at Universidade Federal do Vale do São Francisco (UNIVASF).

A Chi-square test was used to assess if the proportion of males and females that emerged in the laboratory differed from a standard 1:1 Fisherian sex ratio.

\section{Results}

\section{Nesting sites and seasonality}

We identified more than 800 nests. They were distributed in two sites 1500 meters apart. Females constructed the nests in compact sandy soil and on the vertical surface of hard clay escarpments. (Fig 1a, b). The majority of the nests were established on the vegetation-covered ground. Overall, the species was active throughout the year, with two peaks of nesting activity, one from March to April and another from October to November. Nests were not homogeneously distributed in the area, ranging from 1 to 9 nests $/ \mathrm{m}^{2}(3.56 \pm 1.53)$ in the dispersed area and 26 to 42 nests $/ \mathrm{m}^{2}(33.6 \pm 7.12)$ when aggregated.

\section{Nest construction and provisioning behavior}

At the beginning of the nest building, females of Diadasina riparia $(n=6)$ flew low close to the nest site and frequently landing on the ground. They initiated digging in multiple locations until selecting a definitive nest site and immediately started the nest building (Fig 1). For excavation, females made field trips to collect water (Fig 1d), which was regurgitated on the ground, making it soft, and then the soil was then excavated with the mouthparts and legs. The water collection sources were near the nesting sites, from three to 40 meters distance.

Two females built up two nests all over the observation period, three built up three nests, and one built four nests. The females began the nest construction in the middle of the morning (10:00-11:00 a.m.) and ended it the next day (10:0011:00 a.m.). Females start the pollen-collecting trips in the afternoon (12:20-01:40 p.m.) immediately after the conclusion of the digging activity. The number of trips to supply each brood cell ranged from eight to 16 (Fig 2a). Pollen sources were close to nesting sites. The end of daily female activities occurred around 04:20 p.m., when the females obstructed the entrance of the nests with their abdomen, remaining in this position until the next morning.

To finalize the nest building, the females made field trips to gather water. We also visualized the females collecting mud pellets from outside and deposited them inside the nests. The females $(n=6)$ spent between 169-305 $\min (245 \pm 83.8$ min) in indoor activities such as nest building, provision unloading, and oviposition and 42-115 $\min (74 \pm 37.32 \mathrm{~min})$ in outdoor activities such as pollen-collecting trips, water gathering and foraging (Fig $2 b$ ).

Four monitored nests were not completed. One female attempted to usurp a neighbor's nest but being expelled by the host females. We did not visualize the female leaving the following morning in one of these nests, suggesting that it died inside the nest. Another female abandoned the nest after finding Leiopodus trochantericus Ducke there for the second time.

\section{Nest description}

The nest entrances were circular, closed by a mud plug, from which a straight vertical tunnel was dug up, ending in one or more brood cells (Fig 3). Mud pellets were deposited around the nest entrance. The tunnel descended vertically to a depth of 24.77 to $45 \mathrm{~mm}$ ( $33 \pm 7.36 \mathrm{~mm} ; n=5$ nests $)$ and then terminated in one or more brood cells, with most of the 

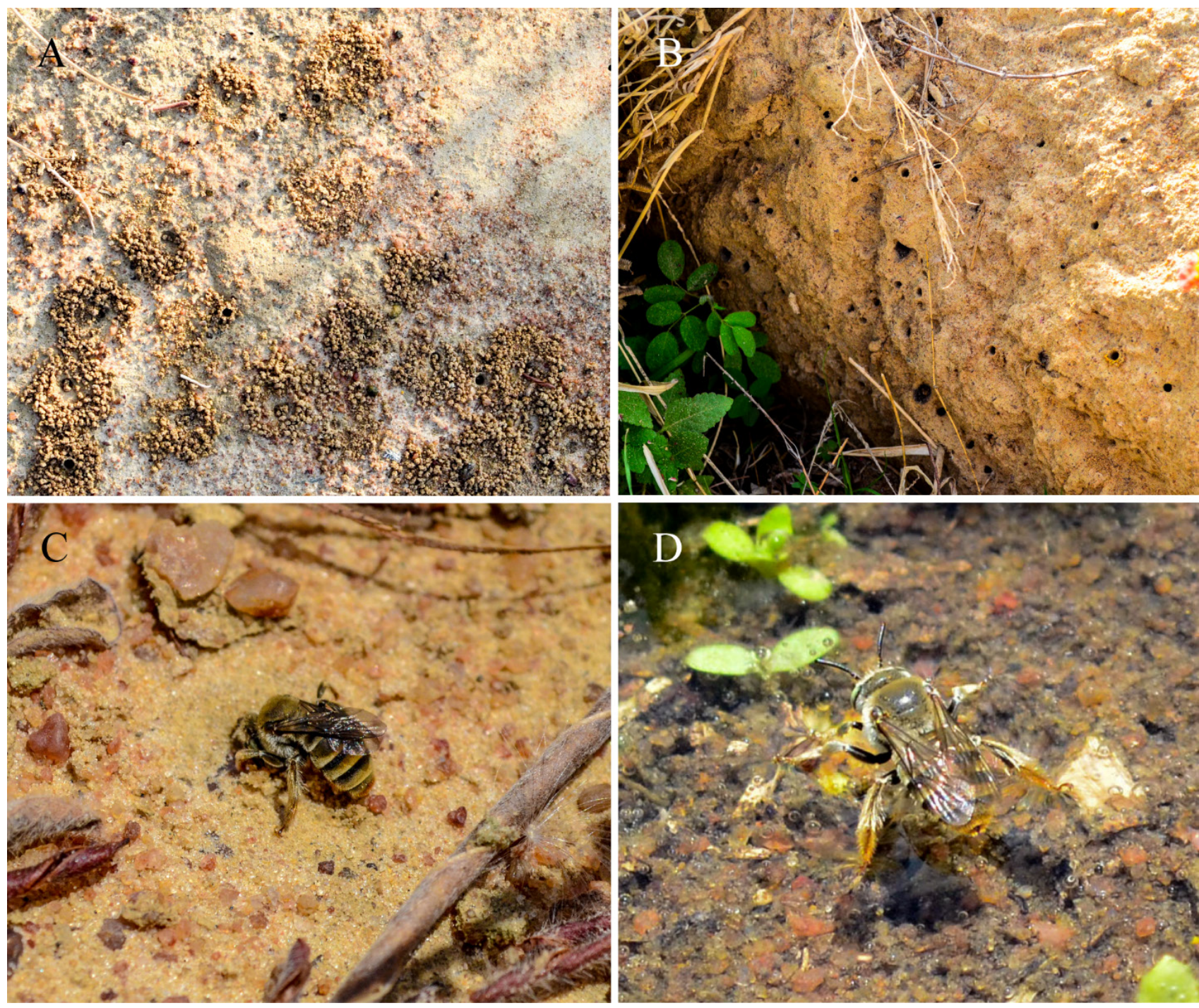

Fig 1. General aspects of the nesting sites and nesting behavior of Diadasina riparia; a. aggregation of Diadasina riparia in flat soil. b. aggregation of Diadasina riparia in vertical surface c. female in the begging of the nest construction. $d$. floating on the water surface during the water-collecting trip.

excavated nests having a single brood cell (Fig 3a). The nests built upon hard clay escarpments had a slightly different structure. The entrance of the nests was arranged in the horizontal position with a tunnel assuming vertical orientation (Fig 3a). In some nests, the construction of septa along the main tunnel was observed (Fig 3c).
A

$$
\text { -Dig } \square \text { Pollen } \square \text { Close }
$$

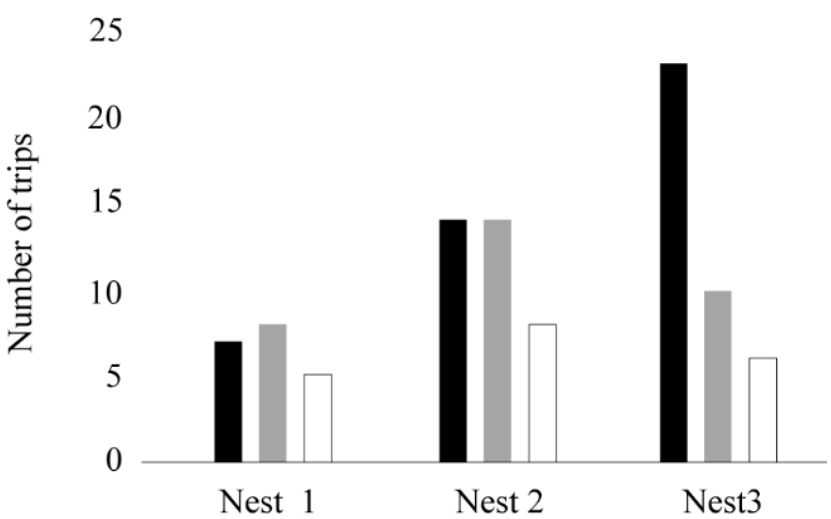

$\mathrm{B}$

$\square$ Outside activity $\quad \square$ Inside activity

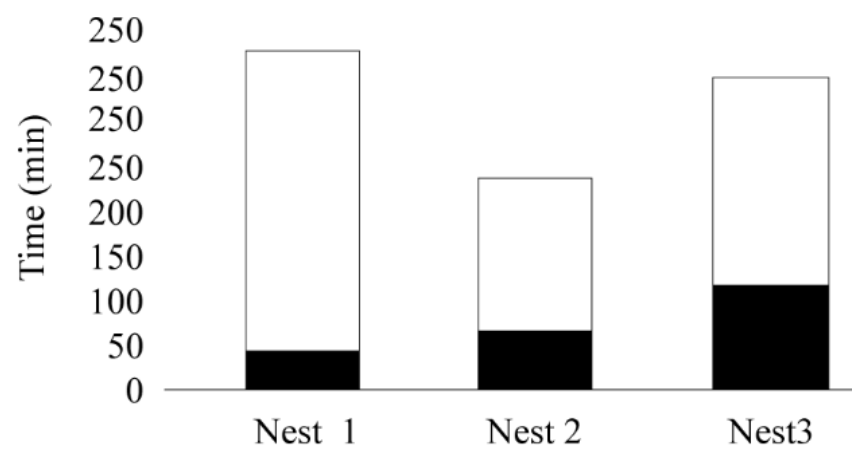

Fig 2. Nesting behavior of a single female of Diadasina riparia to construct three nests; a. number of trips performed during different stages of each nest construction and their purpose. b. Duration of time inside and outside the nest. 
The brood cells were strongly adhered to the ground with vertical to sub-vertical orientation. The brood cells were closed by a slightly convex cap, with an internal surface in a spiral pattern. Brood cells are urn-shaped with length of 7.85 to $11.1 \mathrm{~mm}(9.08 \pm 1.11 \mathrm{~mm} ; n=10)$, minimum diameter ranging from 4.49 to $7.23 \mathrm{~mm}(6.09 \pm 0.66 \mathrm{~mm} ; n=10)$ and maximum diameter of 5.86 to $7.87 \mathrm{~mm}(6.9 \pm 0.99 \mathrm{~mm} ; n=10)$. Inside the brood cells, a mass of orange and compacted pollen was observed. The whitish, elongated, and slightly curved eggs were placed on the bottom of the pollen mass (Fig 3b).
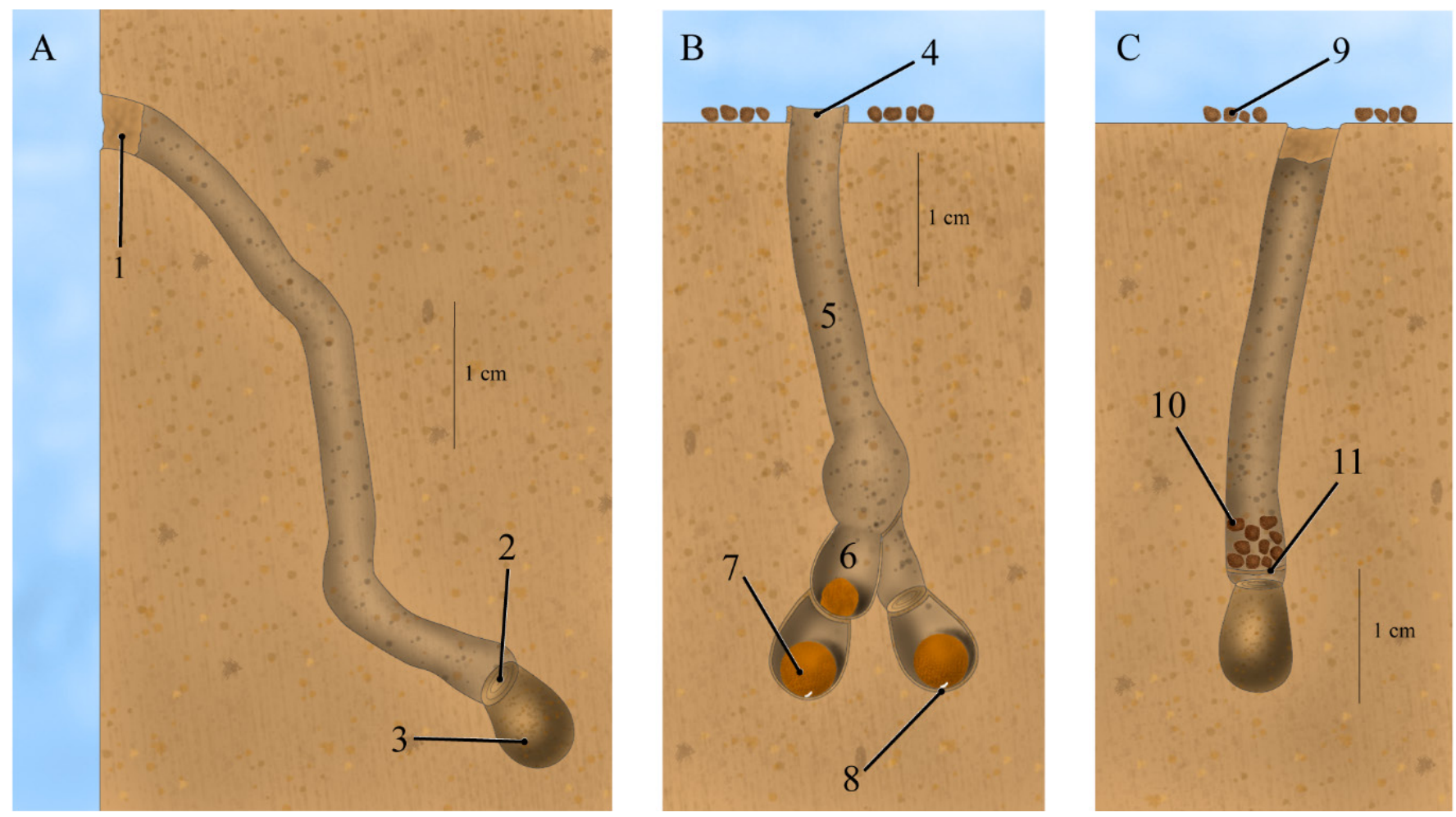

Fig 3. Nest architectures of Diadasina riparia. a. nest from a vertical surface (1. Nest plug in the entrance; 2 . Brood cell cap; 3 . Turret on nest entrance). b-c. nest from flat soil (4. main tunnel; 5. mud pellets deposited inside nest; 6. mud pellets deposited around the entrance; 7. Septa; 8. Egg; 9. spheroid pollen mass).

\section{Life cycle and sex ratios}

From the 200 nests, 34 females (17\%) and 41 males (20.5\%) emerged with a sex ratio with no statistical difference of $1: 1\left(\chi^{2}=0.653, d f=1, p=0.419\right)$. Development time was 13 to 21 days for females (16.58 \pm 3.06 days) and 13 to 45 days for males ( $17.04 \pm 5.25$ days). After eight months, we opened nine nests, in which no emergencies were registered. In these nests, we observed four mature larvae, probably in diapause, one brood cell with dry pollen mass and one fungal brood cell.

\section{Natural enemies}

The most frequent natural enemies were the bombyliid fly Anthrax sp. and the bees of the Protepeolini tribe, $L$. trochantericus. Females of $L$. trochantericus were the main natural enemies present in the aggregations. The kleptoparasite bees had the behavior of waiting near the entrance of the nests, in the soil, or on branches (Fig 4b). Shortly after the host females left their nests, L. trochantericus invaded and spent approximately 30 seconds inside them. A total of 13 adults $L$. trochantericus emerged from the nests. The development time of $L$. trochantericus ranged from 13 to 22 days ( $17.72 \pm 3.37$ days).

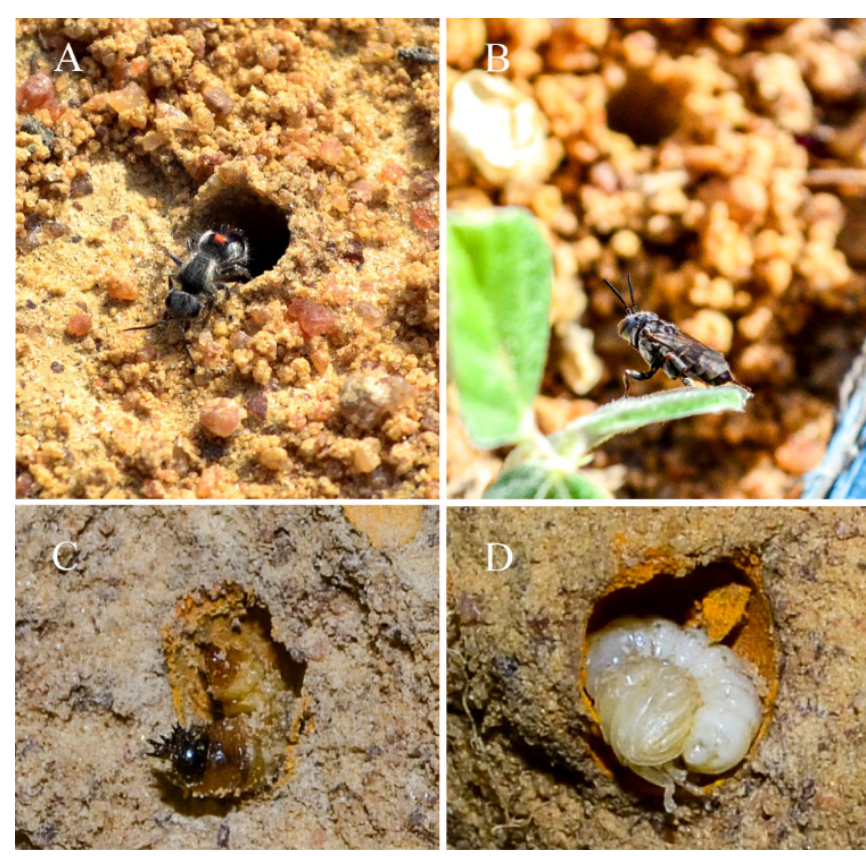

Fig 4. Natural enemies associated with Diadasina riparia. a. female of Mutillidae wasp parasitizing a nest. b. Leiopodus trochantericus females awaiting at the nest entrance. c. Anthrax pupa. d. Brood cell with a larva of a parasite feeding on a pupa of Diadasina riparia. 
The bombyliid fly Anthrax sp. was frequently seen patrolling the aggregation, flying over the nest entrance, and throwing eggs into the nests while the host females were out. Further, the bombyliid fly larvae were frequently seen inside cells that were opened (Fig 4c). The number of Anthrax sp. that emerged from the nests was 13, with development time ranged from 16 to 37 days ( $28.63 \pm 6.23$ days). Various female mutillids were observed at the nest site, entering open nests or digging closed nests (Fig 4a). Two Mutillidae wasps emerged from the nests. We did not observe antagonistic behaviors from host females against parasites.

\section{Discussion}

Our study presented the first record on the nesting biology of Diadasina riparia. The species is multivoltine with nesting activity in both the dry and rainy seasons, confirming the suspicions of Aguiar and Zanella (2005). This characteristic was also observed for D. distincta, which can undergo up to five generations a year (Martins et al., 1990). The females' nest in the ground is a common feature among the group of solitary bees (see in Antoine \& Forrest, 2021). Site selection is an important part of the nesting process. Some locations for nests may be better than others concerning favorable edaphic conditions, proximity to food plants, and/ or reduced parasite loads (Sabino et al., 2020). The more time a female spends searching for the ideal location and creating a nest, the less time she will have to provision and lay eggs in it or construct additional nests (Antoine \& Forrest, 2021). The nesting sites of $D$. riparia are close to areas with frequent irrigation and flower availability throughout the year, which may be the main factor supporting the activity of the species, even in the dry season.

Nevertheless, larvae in nests opened after eight months also indicate a possible diapause in D. riparia within the same population, part of the offspring emerged in a short period [13-45 days]. In contrast, the other part entered a possible diapause of more than eight months. Santos et al. (2019) did an ancestral reconstruction analysis of diapause types in bees. They showed that within Apidae, a clade with $D$. rinconis and Ptilothrix plumata Smith has common ancestrality in developmental diapause, a characteristic preserved in bee species that did not evolve to eusociality. Thus, it is plausible to infer that $D$. riparia shares the same evolutionary basis of diapause with other Emphorini (and even other solitary bee species).

Other Emphorini species have a diapause period as part of their developmental biology. Martins and Antonini (1994) observed diapause in $D$. distincta during the rainy season. Prepupae of $D$. rinconis Cockerell may stay in diapause from one reproductive season to the next one (Neff \& Simpson, 1992). Martins et al. (2001) reported the offspring of P. plumata undergoing diapause at the end of the breeding season, emerging in the following year.
The nests constructed by D. riparia females are mostly single-celled, with a simple and short tunnel, vertically on the surface. This pattern is similar in many aspects to the nests of other emphorines species such as D. distincta (Martins \& Antonini, 1994), P. plumata (Martins et al., 1996; Schildwer et al., 2009), and Ptilothrix bombiformi (Cresson) (Rust, 1980). These similarities in nest architecture may reflect the phylogenetic relationship between the genera Ptilothrix and Diadasina (Roig-Alsina \& Michener, 1993). Although already considered a subgenus of Diadasia (Michener, 1954), the genus Diadasina was later considered the closest part to Ptilothrix (Roig-Alsina \& Michener, 1993). We do not know exactly the benefits associated with building one cell per nest. There are costs associated with digging a new nest for each cell, but on the other hand, this behavior can avoid massive parasitism in one nest with multiple cells. Pathogens and parasites can significantly reduce the survival of bees while nesting (Linsley \& McSwain, 1942), affecting more than 50\% of nest cells in some species (Linsley, 1958).

However, a high number of parasitized nests was still observed in this study. This high number of parasitic nests suggests that the defense mechanisms adopted by the species proved to be inefficient. Leiopodus trochantericus was the most frequent natural enemy in D. riparia nests. There is likely a strong association between this species and the genus Diadasina. This species's only record of parasitism is for nests of D. distincta (Straka \& Bogusch, 2007). Also, parasitism by the Anthrax fly was frequent. This genus has been frequently registered associated with several groups of solitary bees; being also registered in nests of $D$. distincta (Martins \& Antonini, 1994) and P. plumata (Martins et al., 1996; Schlindwein et al., 2009). Besides the strategy to build one cell per nest, some structural features observed in the $D$. riparia nests, such as the closing of the nest and the presence of septa along the tunnel, are probably mechanisms to prevent parasitism of the nests. These mechanisms may guarantee the protection of the nests after their completion. However, they are inefficient against the two main parasites that attack the nests during their construction.

During the observation period, we register evidence that the species is philopatric, nesting in the same site for at least three years (from 2018 to the present). Philopatric behavior is expected in many groups of Hymenoptera and has been associated with food resources available in the area and their resources, such as suitable soil for nesting (Rosenheim, 1990). The tendency of the D. riparia offspring to nest near the places they emerged may be related to the availability of suitable soil areas and their proximity to specific floral resources since the species are considered oligolectic (Schlindwein, 1998). Antonini et al. (2000) reported that the high degree of philopatry observed in D. distincta was mainly related to soil texture at nesting sites. D. riparia prefers to nest in compacted soils, a scarce resource in the study area, limiting the dispersion of the nests. Another behavior 
performed by females was collecting water in their crops to soft the soil and allow the excavation of the nests, similar to that observed in most species of emphorine bees (Linsley et al., 1956; Laroca \& Almeida, 2009). In this way, the presence of puddles of water near the nesting sites can make these areas attractive, as the females use this resource to facilitate the excavation of the nests.

Although the knowledge on the nesting biology of many groups of Emphorini bees is growing, the information is still fragmented and focused on a few species of certain genera, such as Diadasina in which presents only a detailed study on nesting biology. The data available in the present study will contribute to expanding the knowledge about some fundamental aspects related to the biology of the genus Diadasina. Besides, our study showed that $D$. riparia shares several characteristics with species from close groups, such as the genus Ptilothrix, evidencing the phylogenetic relationship between the genera.

\section{Acknowledgments}

The authors thank the two anonymous reviewers for improving the quality of the initial manuscript with their helpful comments. We thank Carlos Martínez (USP) for identifying the bees and Gabriel A. R. Melo (UFPR) for confirming the identification. We also thanks Carlos J. E. Lamas (MZ/USP) for identifying Bombyliidae. We also are grateful to Vashtir R. S. Braga for the help in fieldwork.

\section{Authors' Contributions}

HOJM: conceptualization, investigation, methodology, writingoriginal draft preparation and review

VSF: conceptualization, writing-original draft preparation and review

GPA-J: investigation, methodology

WOS: writing-original draft preparation and review

All authors have read, revised, and agreed to the final version of the manuscript.

\section{Funding}

HOJM is currently funded by a scholarships from Conselho Nacional de Desenvolvimento Científico e Tecnológico - CNPq (134121/2019-8).

\section{Disclosure statement}

The authors declare no conflicts of interest.

\section{References}

Aguiar, C.M. \& Zanella, F.C. (2005). Estrutura da comunidade de abelhas (Hymenoptera: Apoidea: Apiformis) de uma área na margem do domínio da caatinga (Itatim, BA).
Neotropical Entomology, 34: 15-24. doi: 10.1590/S1519566X2005000100003

Amorim-Neto, M.S. (1989). Informações meteorológicas dos Campos Experimentais de Bebedouro e Mandacaru. EMBRAPA-CPATSA, Documento, 57. 58p.

Antoine, C.M., \& Forrest, J.R. (2021). Nesting habitat of ground-nesting bees: a review. Ecological Entomology, 46: 143-159.

Antonini, Y.C., Jacobi, C.M. \& Martins, J.R.P. (2000). Philopatry in the Neotropical ground-nesting solitary digger bee, Diadasina distincta (Holmberg, 1903) (Hymenoptera: Apidae) at a nesting site in southeastern Brazil. Revista de Etologia, 2: 111-119.

Ascher, J.S. \& Pickering, J. (2019). Discover Life bee species guide and world checklist (Hymenoptera: Apoidea: Anthophila). http://www.discoverlife.org/mp/20q?guide=Apoidea species

Batra, S.W. (1984). Solitary bees. Scientific American, 250: 120-127.

Harmon-Threatt, A. (2020). Influence of nesting characteristics on health of wild bee communities. Annual Review of Entomology, 65: 39-56.

Hazeldine, P.L. (1997). Comportamiento de nidificación de Diadasina distincta (Hymenoptera: Apidae). Revista de la Sociedad Entomologica Argentina, 56: 125-130.

Klein, A.M., Vaissière, B., Cane, J.H., Steffan-Dewenter, I., Cunningham, S.A., Kremen, C. \& Tscharntke, T. (2007). Importance of crop pollinators in changing landscapes for world crops. Proceedings of the Royal Society B: Biological Sciences, 274: 303-313.

Laroca, S. \& Almeida, M.C. (2009). On the nesting biology and cleptolectic behavior of a Neotropical bee, Ptilothrix plumata Smith, 1853 (Hymenoptera, Anthophila, Emphorini) in an ecotonal hotspot of savanna in the "cerrado" of Paraná state (Brazil). Boletin de la SEA, 45: 281-288.

Linsley, E. (1958). The ecology of solitary bees. Hilgardia, 27: 543-599.

Linsley, E.G. \& McSwain, J.W. (1942). The parasites, predators, and inquiline associates of Anthophora linsleyi. The American Midland Naturalist, 27: 402-417.

Linsley, E.G. \& McSwain, J.W. \& Smith, R.F. (1956) Biological observations on Ptilothrix sumichrasti (Cresson) and some related groups of emphorine bees (Hymenoptera, Anthophoridae). Bulletin of the Southern California Academy of Sciences, 55: 83-101.

Martins, R.P. \& Antonini, Y. (1994). The biology of Diadasina distincta (Holmberg, 1903) (Hymenoptera: Anthophoridae). Proceedings of the Entomological Society of Washington, 96: 553-560. 
Martins, R.P., Guerra, S.T.M. \& Barbeitos, M.S. (2001). Variability in egg-to-adult development time in the bee Ptilothrix plumata and its parasitoids. Ecological Entomology, 26: 609-616. doi: 10.1046/j.1365-2311.2001.00353.x

Martins, R.P., Guimarães, F.G. \& Dias, C.M. (1996). Nesting biology of Ptilothrix plumata Smith, with a comparison to other species in the genus (Hymenoptera: Anthophoridae). Journal of the Kansas Entomological Society, 69: 9-16.

Michener, C.D. (1964). Evolution of the nests of bees. American Zoologist, 4: 227-239.

Michener, C.D. (2007). The Bees of the World. Baltimore, The Johns Hopkins University Press.

Moure, J.S. \& Melo, G.A.R. (2012). Emphorini Robertson, 1904. In Moure, J.S., Urban, D. \& Melo, G.A.R. (Orgs). Catalogue of Bees (Hymenoptera, Apoidea) in the Neotropical Region - online version. Available at http://www.moure.cria. org.br/catalogue. (accessed date: 12 March, 2021)

Nabhan, G.P. \& Buchmann, S. (1997) Services provided by Pollinators. In G.C. Daily (ed.), Nature's Services, Societal Dependence on Natural Ecosystems, pp 133-150. Island Press, Washington DC.

Neff, J.L. \& Simpson, B.B. (1992). Partial bivoltinism in a ground-nesting bee: the biology of Diadasia rinconis in Texas (Hymenoptera, Anthophoridae). Journal of the Kansas Entomological Society, 65: 377-392.

Roig-Alsina A. \& Michener, C.D. (1993). Studies of the phylogeny and classification of long-tongued bees (Hymenoptera; Apoidea). University of Kansas Science Bulletin, 55: 124-162.

Rosenheim, J.R. (1990). Density-Dependent parasitism and the evolution of aggregated nesting in the solitary Hymenoptera.
Annals of the Entomological Society of America, 83: 277286. doi: 10.1093/aesa/83.3.277

Rust, R.W. (1980). The biology of Ptilothrix bombiformis (Hymenoptera: Anthophoridae). Journal of the Kansas Entomological Society, 53: 427-436.

Sabino, W.O., Alves-dos-Santos, I., Queiroz, E.P., de Faria, L.B., Papaj, D.R., Buchmann, S.L. \& Silva, C.I. (2021). Nesting biology of Centris (Paracentris) burgdorfi (Apidae: Centridini). Journal of Apicultural Research, 60: 817-827. doi: $10.1080 / 00218839.2020 .1717760$

Santos, P.K.F., Arias, M.C. \& Kapheim, K.M. (2019). Loss of developmental diapause as prerequisite for social evolution in bees. Biology Letters, 15: 20190398. doi: 10.1098/rsbl. 2019.0398

Sarzetti, L.C. \& Genise, J.F. (2011). The Nest Architecture of Diadasia hirta (Jörgensen) (Apidae: Emphorini) from La Rioja Province, Northwestern Argentina. Journal of the Kansas Entomological Society, 84: 249-255.

Schlindwein, C. (1998). Frequent Oligolecty Characterizing a Diverse Bee-Plant Community in a Xerophytic Bushland of Subtropical Brazil. Studies on Neotropical Fauna and Environment, 33: 46-59. doi: 10.1076/snfe.33.1.46.2168

Schlindwein, C., Pick, R.A. \& Martins, C.F. (2009). Evaluation of oligolecty in the Brazilian bee Ptilothrix plumata (Hymenoptera, Apidae, Emphorini). Apidologie, 40: 106-116. doi: 10.1051/apido/2008067

Straka, J. \& Bogusch, P. (2007). Phylogeny of the bees of the family Apidae based on larval characters with focus on the origin of cleptoparasitism (Hymenoptera: Apiformes). Systematic Entomology, 32: 700-711. doi: 10.1111/j.13653113.2007.00394.x

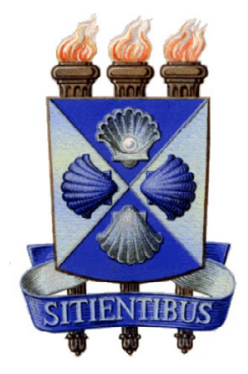

